\title{
The lichens of forest rocky communities of mountain Olovgora (Arkhangelsk Region, Northwest Russia)
}

\author{
Viktoria N. Tarasova ${ }^{1}$, Angella V. Sonina ${ }^{1}$, Vera I. Androsova ${ }^{1} \&$ \\ Irina S. Stepanchikova ${ }^{2,3}$ \\ ${ }^{1}$ Department of Botany and Plant Physiology, Petrozavodsk State University, 33 Lenin St., 185910 Petrozavodsk, Russia. \\ E-mails: vika18@sampo.ru,vera28@karelia.ru, angella_sonina@mail.ru \\ ${ }^{2}$ Department of Botany, St. Petersburg State University, 7/9 Universitetskaya emb., 199034 St.-Petersburg, Russia. \\ E-mail: stepa_ir@mail.ru \\ ${ }^{3}$ Laboratory of Lichenology and Bryology, the Komarov Botanical Institute of RAS, 2 Professor Popov St., \\ 197376 St. Petersburg, Russia
}

\begin{abstract}
The present study reports 223 species and three subspecies of lichens from forest rocky communities of mountain Olovgora, which is the highest point of the Vetreny Poyas ridge (Arkhangelsk Region, NW Russia). A total of 82 species are new for the mainland area of Arkhangelsk Region. The species Bryoria glabra has been reported for the first time for European Russia. Two recorded lichen species, Cladonia bellidiflora and Lobaria pulmonaria, are in the Red Data Book of Arkhangelsk Region. The occurrence of old-growth forests, high heterogeneity of conditions, presence of an altitudinal gradient and the proximity to the sea lead to the rich diversity of lichens in this area.
\end{abstract}

Keywords: lichens, rocky communities, old-growth forest, mountain Olovgora, Arkhangelsk Region

\section{INTRODUCTION}

At the present time, the lichen diversity of Arkhangelsk Region (NW Russia) is poorly known compared with other regions of Russia. The data on the lichens of this area are insufficient: there is no list of lichens for this territory, and, consequently, no data on the total number of lichen species. However, Arkhangelsk region is a vast territory $\left(589,900 \mathrm{~km}^{2}\right)$, which includes plains of northern and middle taiga (northern and middle boreal subzone) with a relatively high percentage of old-growth forests, seashores, limestone outcrops, as well as a large area of Arctic islands. Such heterogeneity of landscapes in the territories leads to the presence of a rich lichen diversity.

There have been only a few published studies for the region. The Arctic islands (the archipelago of Novaya Zemlya, Franz Josef Land partly) form the most lichenologically studied area of Arkhangelsk Region: more than 500 species of lichens are known from the islands (Andreev et al., 1996). For the mainland area of the region, only 350 species are known from different publications (Table 1). Moreover, there are scattered notes about lichenological findings on the territory of Arkhangelsk region. About 50 species were reported in different editions of Handbooks of lichens of Russia (Handbook...,
1971-1978; Handbook..., 1996-2008). In addition, K. A. Rassadina described the new species Hypogymnia incurvoides Rassad. sampled by V. P. Savicz in 1917 from Arkhangelsk Region (Rassadina, 1967; McCune et al., 2006). In the recent publication the species Platismatia norvegica (Lynge) W. L. Culb. \& C. F. Culb. was reported from the Arkhangelsk Region as new to European Russia (Tarasova, 2014).

The lichen diversity of the neighbouring territories has been studied much better: for Murmansk Region 1029 species of lichens are known (Urbanavichus et al., 2008), the Republic of Karelia has about 1256 species (Fadeeva et al., 2007), the Republic of Komi - 1147 species (Pystina \& Hermansson, 2013), Vologda Region is poorly studied and has 182 revealed species of lichens only (Rassadina, 1929; Chkhobadze, 1997; Notov et al., 2006).

Olovgora is a highland open to sea winds. The slopes of the ridge are covered with rocky forest communities typical of northern Fennoscandia. The old-growth forests, the high heterogeneity of habitats, the presence of an altitudinal gradient and the proximity of the White Sea determine the interest in the study and suggest a rich diversity of lichens in this area. Studies of lichens have never been carried 
Table 1. Number of lichen species in different localities of the mainland area of Arkhangelsk region according to published data

\begin{tabular}{|c|c|c|c|}
\hline Locality & Area & Number of species & Citation sources \\
\hline Pinezhsky Reserve & $518,9 \mathrm{~km}^{2}$ & 134 & $\begin{array}{l}\text { Zakharchenko, 1989; } \\
\text { Zakharchenko \& Sokolova, } \\
\text { 1989; Puchina et al., } 2000\end{array}$ \\
\hline Nature Park "Kozhozero" & $2,020 \mathrm{~km}^{2}$ & 209 & $\begin{array}{l}\text { Fadeeva \& Kravchenko, } \\
\text { 2005a, 2005b; Fadeeva, } 2006\end{array}$ \\
\hline $\begin{array}{l}\text { Watershed territories between the } \\
\text { Northern Dvina and the Pinega rivers in } \\
\text { NW Russia }\end{array}$ & $34,500 \mathrm{~km}^{2}$ & 104 & Glushkovskaya, 2013 \\
\hline $\begin{array}{l}\text { Mountain Muroigora, the Vetreny Poyas } \\
\text { ridge }\end{array}$ & $0.04 \mathrm{~km}^{2}$ & 128 & $\begin{array}{l}\text { Tarasova \& Sonina, 2011a, } \\
2011 \text { b, } 2012\end{array}$ \\
\hline The coast of Bolshoy Solovetsky Island & $0.2 \mathrm{~km}^{2}$ & 35 & Sonina \& Markovskaya, 2013 \\
\hline
\end{tabular}

out in this territory. This paper is the outcome of comprehensive lichenological studies of mountain Olovgora and a contribution to the general knowledge on the regional lichen biota.

\section{MATERIALS AND METHODS}

\section{Study area}

The study area is located in the northwestern part of Arkhangelsk Region, $45 \mathrm{~km}$ south of the Onega Bay of the White Sea (Fig. 1). Olovgora $\left(344 \mathrm{~m}\right.$ a. s. $1 ., 63^{\circ} 24^{\prime} \mathrm{N}, 37^{\circ} 00^{\prime} \mathrm{E}, 0.7 \times 0.5 \mathrm{~km}$ in size) is the highest point of the low-mountain ridge Vetreny Poyas. This ridge, which is about $200 \mathrm{~km}$ long and 10-15 km wide, stretches along the southern coast of the Onega Bay. It is a part of the Baltic Shield and forms the watershed of the rivers flowing into the White Sea and the Baltic Sea, clearly rising above the surrounding lowlands. The ridge has a steep northern slope and a flat-lying southern slope and consists of several ridges $200-300 \mathrm{~m}$ high, elongated in the south-easterly direction. Olovgora is an outcrop of the solid Proterozoic crystalline ultrabasic rocks - komatiitic basalts in the form of debris blocks of different size (Kulikova et al., 2007). The soils are mostly underdeveloped: primitive rock or thin and peaty podzols.

The climate is characterized by frequent weather changes. The lack of ridges around makes this area easily accessible to the cyclones from the Atlantic and from the North-East. The cyclones bring precipitation, cloudy weather, and warming in winter, the cold Arctic air flows cause a strong temperature decline and frosts. The annual precipitation ranges from 400 to $540 \mathrm{~mm}$ with up to 200 days with precipitation - snowfalls of short duration in winter and long drizzles in autumn. The humidity is relatively high: $85-95 \%$ in autumn and winter, 70-90\% in summer and spring. The depth of snow cover reaches 70-80 cm (Gromtsev, 2008).

The vegetation of Olovgora is represented by sparse spruce forests, with a predominance of Picea obovata Ledeb. and Betula pubescens Ehrh., and with individual trees of Sorbus aucuparia L., Salix caprea L., Populus tremula L. and Pinus sylvestris L. The terrestrial cover is dominated by Vaccinium myrtillus L., V. vitisidaea L., Ledum palustre L., Calluna vulgaris (L.) Hull., as well as a variety of green mosses, liverworts and lichens. Most of the plant communities of Olovgora are old-growth forests without any traces of logging and fires, where natural forest dynamics can be observed. The age of some trees comes up to 300 years, and there is a large supply of dead wood. The vegetation on the plains of Olovgora is represented by extensive bogs and young forests, recovering after clearcuttings.

\section{Data collection}

The field work was carried out by the first three authors during two expeditions in June 2012 and 2013. A total of 11 sample plots $20 \times 20 \mathrm{~m}$ were established along two transects on the northern (306-341 m a. s. 1., 63 $244^{\prime} 50-55^{\prime \prime} \mathrm{N}$, $\left.37^{\circ} 00^{\prime} 28-30^{\prime \prime} \mathrm{E}\right)$ and southern (302-338 $\mathrm{m}$ a. s. $\left.1 ., 63^{\circ} 24^{\prime} 35-43^{\prime \prime} \mathrm{N}, 37^{\circ} 00^{\prime} 12-16^{\prime \prime} \mathrm{E}\right)$ slopes of 


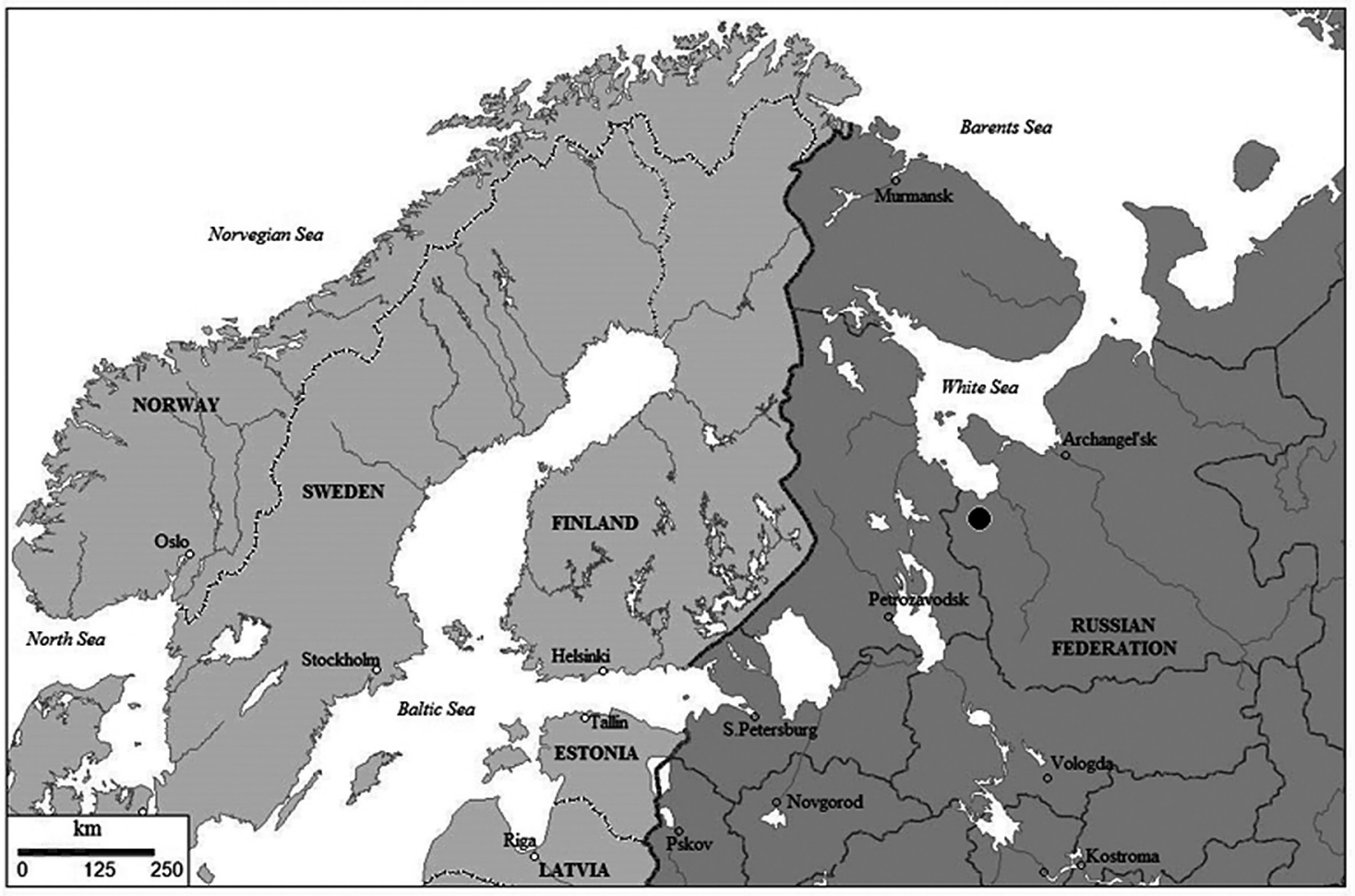

Fig.1. The location of mountain Olovgora (Arkhangelsk Region, Northwest Russia) - •

mountain Olovgora in old-growth spruce forests. A detailed geobotanical description of the rocky forest community was made for each sample plot including the registration of trees (height, age, basal area, crown density etc.) and the ground cover characteristics (shrub and herb cover, mosses and lichen cover). The epiphytic, epilithic $(10 \times 20 \mathrm{~cm}$ plots $)$ and ground lichen communities $(1 \times 1 \mathrm{~m}$ plots $)$ were described in detail. In addition, in order to explore the overall species diversity of lichens, routes covering the entire territory of Olovgora were set up. The total area of the investigated territory was 0.44 ha in the sample plots and about 25 ha by means of walking.

The collected material, a total of 2000 lichen specimens, was identified using a standard microscopic technique and spot tests. The sampled specimens of genera Cladonia and sterile crustose lichen species were identified by a standard technique of high performance thinlayer chromatography (HPTLC) in Laboratory of Lichenology and Bryology of BIN RAS, St. Petersburg, and Herbarium of the Botanical Museum,
University of Helsinki, using solvent systems A, $\mathrm{B}$ and C (Orange et al., 2001). The nomenclature follows mainly Nordin et al. (2011).

The specimens are deposited in the herbarium of Petrozavodsk State University (PZV).

\section{List of localities}

Arkhangelsk Region, Onega District, the Vetreny Poyas ridge, mountain Olovgora:

1) lower part of the southern slope (302-320 $\mathrm{m}$ a. s. $\left.1 ., 63^{\circ} 24^{\prime} 35-39^{\prime \prime} \mathrm{N}, 37^{\circ} 00^{\prime} 11-14^{\prime \prime} \mathrm{E}\right)$;

2) top part of the southern slope (321-332 $\mathrm{m}$ a. s. 1., 6324'40-41"N, 3700'14-16”E);

3) lower part of the northern slope (306-321 $\mathrm{m}$ a. s. $\left.1 ., 63^{\circ} 24^{\prime} 53-54^{\prime \prime} \mathrm{N}, 37^{\circ} 00^{\prime} 29-31^{\prime \prime} \mathrm{E}\right)$;

4) top part of the northern slope (329-337 $\mathrm{m}$ a. s. 1., $63^{\circ} 24^{\prime} 51-53^{\prime \prime} \mathrm{N}, 37^{\circ} 00^{\prime} 28-30$ ”'E);

5) central part of the plateau (338-341 $\mathrm{m}$ a. s. 1., 6324'42-50”N, 3700'16-29”E);

6) western part of plateau (326-339 $\mathrm{m}$ a. s. 1., $63^{\circ} 24^{\prime} 38-51^{\prime \prime} \mathrm{N}, 37^{\circ} 00^{\prime} 12-14^{\prime \prime} \mathrm{E}$ );

7) eastern part of the plateau (319-335 $\mathrm{m}$ a. s.

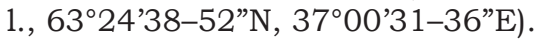




\section{THE SPECIES}

For each species the substrates and numbers of localities (see above) are listed. Abbreviations and symbols: \# - lichenicolous fungi; + - nonlichenized fungi; * - the species is new for the mainland part of Arkhangelsk Region.

*AdElolecia kOlaËnsis (Nyl.) Hertel \& Rambold on rocks and boulders; 4, 5 .

Alectoria SARMENTOSA (Ach.) Ach. - on trunks of Picea obovata and Betula pubescens, on snags of coniferous trees; $1-7$.

Amandinea Punctata (Hoffm.) Coppins \& Scheid. - on trunks of Sorbus aucuparia; 1.

ARCTOPARMELIA CENTRIFUGa (L.) Hale - on rocks and boulders; 1,2 .

ARCTOPARMElia Incurva (Pers.) Hale - on rocks and boulders; 5 .

ARTHONIA DIDYMA Körb. - on trunks and branches of Picea obovata; 4. Confirm. D. Himelbrant, 2015.

*ARTHONIA DISPUNCTA Nyl. - on trunks of Sorbus aucuparia; 4. Confirm. D. Himelbrant, 2015.

*ARTHONia PATEllulata Nyl. - on trunks of Sorbus aucuparia; 1. Confirm. D. Himelbrant, 2015.

*ARTHONia RAdiata (Pers.) Ach. - on trunks of Sorbus aucuparia; 1, 3. Confirm. D. Himelbrant, 2015.

+ARTHOPYRENIA GRISEA (Schleich. ex Schaer.) Körb. - on fallen trees of Betula pubescens and Picea obovata; 2, 5. Confirm. D. Himelbrant, 2015.

$+{ }^{*}$ ARthothelium scandinavicum Th. Fr. - on trunks and branches of Picea obovata; 1, 2. Confirm. D. Himelbrant, 2015.

*ARTHRORHAPHIS Citrinella (Ach.) Poelt - on soil; 7.

*Aspicilia laevata (Ach.) Arnold - on boulders and rocks; 1, 2.

*Athallia Pyracea (Ach.) Arup et al.- on trunks of Populus tremula; 6. Confirm. D. Himelbrant, 2015.

BACIDIA subincompta (Nyl.) Arnold - on trunks of Sorbus aucuparia; 3. Confirm. D. Himelbrant, 2015.

BAEOMYCES CARNEUS Flörke - on boulders and rocks; $2,3$.

Baeomyces Rufus (Huds.) Rebent. - on base of boulders, 1 ; on stumps, 3 .

Bellemerea cinereorufescens (Ach.) Clauzade \& Cl. Roux - on boulders and rocks; 2 .

BiATORA GLOBUlOSA (Flörke) Fr. - on trunks of Sorbus aucuparia; 3. Det. D. Himelbrant, 2015.

*Biatora helvola Körb. ex Hellb. - on trunks of
Sorbus aucuparia, 3; on trunks of Populus tremula, 5. Det. D. Himelbrant, 2015.

*Biatora ocelliformis (Nyl.) Arnold - on trunks of Betula pubescens, on standing deadwood of Pinus sylvestris; 2. Confirm. D. Himelbrant, 2015.

*Biatora subduplex (Nyl.) Räsänen ex Printzen on trunks of Sorbus aucuparia; 4. Confirm. D. Himelbrant, 2015.

*BRyoria BICOLOR (Ehrh.) Brodo \& D. Hawksw. - on trunks of Picea obovata, on standing deadwood of Pinus sylvestris and Picea obovata; 2; on trunks of Picea obovata, on soil; 3, 5. Confirm. L. Myllys, 2014.

Bryoria CAPILlaris (Ach.) Brodo \& D. Hawksw. - on trunks of Picea obovata, on standing deadwood of Picea obovata; 1-7. Confirm. L. Myllys, 2014.

BRyoria FURCEllata (Fr.) Brodo \& D. Hawksw. - on trunks of Betula pubescens and Picea obovata; $1-7$.

BRYORIA FUSCESCENS (Gyeln.) Brodo \& D. Hawksw. - on trunks and standing deadwood of Picea obovata; 1-7. Confirm. L. Myllys, 2014.

*Bryoria Glabra (Motyka) Brodo \& D. Hawksw. - on trunks of Picea obovata; 1. Confirm. L. Myllys, 2014.

BRYORIA IMPleXa (Hoffm.) Brodo \& D. Hawksw. - on trunks of Picea obovata and Betula pubescens, on standing deadwood of Picea obovata; 1-7. Confirm. L. Myllys, 2014.

BRYoRIA NADVORNiKiana (Gyeln.) Brodo \& D. Hawksw. - on trunks of Picea obovata, Salix caprea and Betula pubescens, on standing deadwood of Pinus sylvestris; 1-7. Confirm. L. Myllys, 2014.

BuELLIA DISCIFORMIS (Fr.) Mudd - on trunks of Sorbus aucuparia; 1.

Calicium glaucellum Ach. - on trunks of Picea obovata, on standing deadwood of Picea obovata; SS; on trunks of Picea obovata; $1,2,4,5$.

CAlicium trabinellum (Ach.) Ach. - on trunks of Betula pubescens, on standing deadwood of Pinus sylvestris; 2; on trunks of Betula pubescens; 4.

CAlicium viride Pers. - on trunks of Picea obovata, on standing deadwood of Picea obovata; 2-5.

${ }^{*}$ Caloplaca borealis (Vain.) Poelt - on trunks of Populus tremula; 5.

*Caloplaca Phaeocarpella (Nyl.) Zahlbr. - on trunks of Sorbus aucuparia; 1. 
${ }^{*}$ Catinaria Atropurpurea (Schaer.) Vězda $\&$ Poelt - on trunks of Populus tremula; 3.

CETRARIA ERICETORUM Opiz - on soil; 3.

Cetraria islandica (L.) Ach. - on soil; 4, 5.

*Cetraria odontella (Ach.) Ach. - on soil, on rocks, on trunks of Picea obovata; 1-7.

CETRARIA SEPINCOla (Ehrh.) Ach. - on trunks of Picea obovata, Betula pubescens and Sorbus aucuparia; 1-7.

ChaEnotheca CHRYsocephala (Turner ex Ach.) Th. Fr. - on trunks of Picea obovata, on standing deadwood of Picea obovata; 1, 2, 4, 5.

Chaenotheca ferruginea (Turner ex Sm.) Mig. on trunks of Picea obovata; 1, 5 .

CHAENotheca SUbRoscida (Eitner) Zahlbr. - on trunks of Picea obovata; 2, 3, 5.

CHAENOTHECA TRICHIALIS (Ach.) Hellb. - on trunks of Picea obovata, on standing deadwood of Picea obovata; $1-5$.

\#ChaEnotheCopsis Consociata (Nádv.) A. F. W. Schmidt - on thalli of Chaenotheca chrysocephala of trunks of Picea obovata; 2, 3, 5.

\#*CHAENOTHECOPSIS EPITHALlina Tibell - on Chaenotheca trichialis of trunks of Picea obovata; 2,5 .

$+{ }^{*}$ Chaenothecopsis fennica (Laurila) Tibell - on trunks of Picea obovata, on standing deadwood of Picea obovata; 1-7.

\#Chaenothecopsis saVonica (Räsänen) Tibell - on lignum of Picea obovata, on stumps, on thalli of Chaenotheca ferruginea; 3.

*Cladonia albonigra Brodo \& Ahti - on soil; 2, 4. The specimens contain fumarprotocetraric acid complex. Det. T. Ahti, 2014.

Cladonia Amaurocraea (Flörke) Schaer. - on soil; 1-7. Confirm. T. Ahti, 2014.

Cladonia ARbuscula (Wallr.) Flot. - on soil; 1-3.

Cladonia BACILliformis (Nyl.) Glück - on trunks of Picea obovata, Betula pubescens, on standing deadwood of Pinus sylvestris, on rotting wood; 1-7. Confirm. T. Ahti, 2014.

Cladonia Bellidiflora (Ach.) Schaer. - on soil; $4,5$.

Cladonia borealis S. Stenroos - on soil; $2-4$. The specimen contains usnic and barbatic acids.

Cladonia botrytes (K. G. Hagen) Willd. - on soil, on rotting wood; $2,3$.

Cladonia Carneola (Fr.) Fr. - on base of trunks of Picea obovata and Betula pubescens, on soil, on rotting wood; 1, 2, 4, 5. Det. T. Ahti, 2014.

Cladonia Cenotea (Ach.) Schaer. - on soil, on rotting wood, on base of trunks of Betula pubescens, Picea obovata, on standing deadwood of Betula pubescens; 1-7.

Cladonia coccifera (L.) Willd. - on soil, on base of trunks of Picea obovata; 1, 2, 4, 5. Det. T. Ahti, 2014.

Cladonia Coniocraea (Flörke) Spreng. - on base of trunks of Betula pubescens; 5. Confirm. T. Ahti, 2014.

Cladonia Cornuta (L.) Hoffm. - on soil, on standing deadwood of Betula pubescens, on rotting wood; $1-4$.

*Cladonia cornuta subsp. groenlandica (Å. E. Dahl) Ahti - on soil; 4. Det. T. Ahti, 2014.

Cladonia CRISPATA (Ach.) Flot. - on soil, on rotting wood; $1-5$.

${ }^{*}$ Cladonia cf. CRYPTOCHLOROPHAEA Asahina - on soil, on standing deadwood of Betula pubescens; 4,5 . The podetia react $\mathrm{C}+$ red. Det. T. Ahti, 2014.

${ }^{*}$ Cladonia cyanipes (Sommerf.) Nyl. - on soil; 2. Det. T. Ahti, 2014.

Cladonia deformis (L.) Hoffm. - on soil, on rotting wood; $1,2,4,5$.

Cladonia digitata (L.) Hoffm. - on soil, base of trunks of Betula pubescens and Picea obovata, on standing deadwood of Pinus sylvestris, on rotting wood; $1,2,4,5$.

Cladonia Fimbriata (L.) Fr. - on base of trunks of Picea obovata, on rotting wood; 3, 5 .

${ }^{*}$ Cladonia GRacilis (L.) Willd. subsp. elongata (Wulfen) Vain. - on soil, on standing deadwood of Betula pubescens; 1-7. Det. T. Ahti, 2014.

Cladonia GRACILIS subsp. GRACILIS - on soil; 2, 4, 5. Det. T. Ahti, 2014.

Cladonia GRACIlis subsp. Turbinata (Ach.) Ahti on soil; 2, 4. Det. T. Ahti, 2014.

${ }^{*}$ Cladonia cf. GRayi G. Merr. ex Sandst. - on soil, on standing deadwood of Betula pubescens, on rotting wood; 2-4. Det. T. Ahti, 2014.

Cladonia macilenta Hoffm. - on soil; 2. Confirm. T. Ahti, 2014.

*Cladonia macrophylla (Schaer.) Stenh. - on soil, on standing deadwood of Betula pubescens; 2-5. Confirm. T. Ahti, 2014.

${ }^{*}$ Cladonia maxima (Asahina) Ahti - on soil; 2, 5. Det. T. Ahti, 2014.

Cladonia merochlorophaea Asahina - on soil; 2. The specimens contain merochlorophaeic and 4-0-methylcryptochlorophaeic acids, fumarprotocetraric acid complex. Det. T. Ahti, 2014. 
Cladonia mitis Sandst. - on soil; 2-5.

Cladonia NORVEGICA Tønsberg \& Holien - on base of trunks of Picea obovata; 5. Det. T. Ahti, 2014.

CLADONIA OCHROCHLORA Flörke - on base of trunks of Picea obovata, on standing deadwood of Betula pubescens; 4, 5. Det. T. Ahti, 2014.

Cladonia PHYLlOPHORA Hoffm. - on soil, on rotting wood; 4, 5. Det. T. Ahti, 2014.

Cladonia Pleurota (Flörke) Schaer. - on soil, on base of trunks of Picea obovata and Betula pubescens, on standing deadwood of Betula pubescens, on rotting wood; 1-7.

Cladonia PYXIDATA (L.) Hoffm. - on soil, on standing deadwood of Betula pubescens; $3-5$. The specimens contain fumarprotocetraric acid complex. Det. T. Ahti, 2014.

Cladonia RANGiferina (L.) F. H. Wigg. - on soil, on rotting wood; $1,3,4$.

Cladonia sQuamosa Hoffm. - on soil, on base of trunks of Picea obovata; 1-5.

Cladonia stellaris (Opiz) Pouzar \& Vězda - on soil; 4.

${ }^{*}$ Cladonia Straminea (Sommerf.) Flörke - on soil; 2. The specimen contains usnic, didymic, squamatic acids and terpenoids. Det. T. Ahti, 2014.

Cladonia stygia (Fr.) Ruoss - on soil; 1-7.

Cladonia subfurcata (Nyl.) Arnold - on soil; 2-4, 6. Det. T. Ahti, 2014.

Cladonia subulata (L.) Weber ex F. H. Wigg. - on soil, on base of trunks of Picea obovata; 1 , 2. Det. T. Ahti, 2014.

Cladonia sulphurina (Michx.) Fr. - on soil, on base of trunks of Betula pubescens, on standing deadwood of Betula pubescens; 1-7.

${ }^{*}$ Cladonia turgida Hoffm. - on soil; 7. Det. T. Ahti, 2014.

Cladonia uncialis (L.) F. H. Wigg. - on soil; 5.

${ }^{*}$ Clauzadea monticola (Ach.) Hafellner \& Bellem. - on boulders and rocks; 1, 2.

${ }^{*}$ Coenogonium Pineti (Ach.) Lücking \& Lumbsch - on mosses over rock; 1.

Cyphelium inquinans (Sm.) Trevis. - on standing deadwood of Picea obovata; 2.

Cystocoleus ebeneus (Dillwyn) Thwaites - on boulders and rocks; 1, 2, 5 .

Dibaeis baeomyces (L. f.) Rambold \& Hertel - on boulders and rocks; 5 .

Diploschistes SCRUPOSUS (Schreb.) Norman - on boulders and rocks; 1, 2, 4 .
Evernia Divaricata (L.) Ach. - on standing deadwood of Picea obovata, on trunks of Picea obovata; 5.

Evernia MESOMORPHA Nyl. - on trunks of Picea obovata; 2.

*Flavocetraria nivalis (L.) Kärnefelt \& A. Thell - on soil; 6.

FuscideA PUSILLA Tønsberg - on trunks of Sorbus aucuparia, 3; on trunks of Pinus sylvestris, 6. The specimens contain divaricatic acid.

*Helocarpon crassipes Th. Fr. - on soil, on mosses, on primary soil over rocks; $3,4$. Det. G. Urbanavichus, 2014.

Hypocenomyce scalaris (Ach.) M. Choisy - on trunks of Picea obovata; 1.

HyPogymnia BITTERI (Lynge) Ahti - on trunks of Betula pubescens and Picea obovata, on standing deadwood of Betula pubescens; 3, 5 .

HyPOGYMNiA PHYSODES (L.) Nyl. - on base of trunks of Betula pubescens, Picea obovata, on standing deadwood of Picea obovata; 1-7.

HyPogymnia TUBulosa (Schaer.) Hav. - on trunks of Betula pubescens, Picea obovata and Salix caprea, on standing deadwood of Picea obovata; 1-7.

Hypogymnia vittata (Ach.) Parrique - on trunks of Picea obovata, on standing deadwood of Betula pubescens and Picea obovata; 2, 4, 5.

ICMADOPHILA ERICETORUM (L.) Zahlbr. - on rotting wood; 1,3 . The specimens contain thamnolic and perlatolic acids.

Imshaugia AleuRites (Ach.) S. L. F. Mey. - on trunks of Picea obovata; 1, 2, 5.

*Japewia subaurifera Muhr \& Tønsberg - on trunks of Picea obovata, Betula pubescens and Salix caprea, on standing deadwood of Pinus sylvestris; 1, 2, 4-6.

*JAPEWIA TORNOËNSIS (Nyl.) Tønsberg - on trunks of Picea obovata and Betula pubescens, on standing deadwood of Picea obovata; 1, 2, 4, 5 .

LeCANia CYRTElla (Ach.) Th. Fr. - on trunks of Sorbus aucuparia; 3.

LECANORA CIRCUMBOREALIS Brodo \& Vitik. - on trunks of Sorbus aucuparia and Betula pubescens, 2-4; on trunks of Populus tremula, 5. Confirm. D. Himelbrant, 2015.

*LeCANora fuscescens (Sommerf.) Nyl. - on trunks of Sorbus aucuparia,on trunks of Betula pubescens; 2, 5. 
*LeCANORA hypopta (Ach.) Vain. - on standing deadwood of Betula pubescens; 4. Det. D. Himelbrant, 2015.

*LECANORA HYPOPTELla Grummann - on trunks of Picea obovata; 5. Det. D. Himelbrant, 2015.

LECANORA INTRICATA (Ach.) Ach. - on boulders and rocks; $1,2,5$.

*LeCANORA Phaeostigma (Körb.) Almb. - on trunks of Picea obovata; 1, 5.

*Lecanora polytropa (Ehrh. ex Hoffm.) Rabenh. - on boulders and rocks; 1, 2.

LECANORA PULICARIS (Pers.) Ach. - on trunks of Sorbus aucuparia, 1, 3, 4; on trunks of Picea obovata, 5 .

*Lecidea Albofuscescens Nyl. - on trunks of Picea obovata, 2, 4, 5; on trunks of Sorbus aucuparia, 1. Confirm. D. Himelbrant, 2015.

*LECIDEA LEPRARIOIDES Tønsberg - on trunks of Picea obovata; 5. Confirm. D. Himelbrant, 2015.

*LECIDEA NYLANDERI (Anzi) Th. Fr. - on trunks of Picea obovata; 2.

*Lecidea pullata (Norman) Th. Fr. - on trunks of Picea obovata, Betula pubescens, Sorbus aucuparia, Populus tremula and Salix caprea; 1, 2, 4, 5. The specimens contain sphaerophorin.

*LECIDEA TESSELlata Flörke - on rocks; 4.

*Lecidea turgidula Fr. - on trunks of Picea obovata; 2.

*Lepraria elobata Tønsberg - on trunks and branches of Picea obovata; 5 . The specimen contains atranorin, zeorin and stictic acid complex.

*LePRARIA JACKII Tønsberg - on trunks and branches of Picea obovata, on standing deadwood of Picea obovata; $1-5$. The specimens contain atranorin, roccellic/angardianic, jackinic/rangiformic and norjackinic/ norrangiformic acid.

LEPRARIA NEGLECTA (Nyl.) Erichsen - on soil; 1, 2, 4. The specimens react $\mathrm{KC}+$ red. Det. T. Ahti, 2014.

*LEPTORHAPHIS ATOMARIA (Ach.) Szatala - on trunks of Populus tremula; 5. Confirm. D. Himelbrant, 2015.

+LePTORHAPHIS EPIDERMidis (Ach.) Th. Fr. - on trunks of Betula pubescens; 1-7.

LOBARIA PUlmonaria (L.) Hoffm. - on trunks of Betula pubescens; 5.

LOBARIA SCROBICULATA (Scop.) DC. - on trunks of Betula pubescens, on standing deadwood of Betula pubescens; 4, 5.
Loxospora elatina (Ach.) A. Massal. - on trunks and branches of Picea obovata, on standing deadwood of Picea obovata; 1, 2, 5. The specimens contain thamnolic and elatinic acids.

Melanelia hepatizon (Ach.) A. Thell - on boulders and rocks; 2.

Melanelia stygia (L.) Essl. - on boulders and rocks; $1,2,4,5$.

Melanohalea olivacea (L.) O. Blanco et al. - on trunks of Betula pubescens, Picea obovata, Sorbus aucuparia and Salix caprea; 1, 2, $4,5$.

MELANOHALEA SEPTENTRIONALIS (Lynge) O. Blanco et al. - on trunks of Betula pubescens; 2, 3, 5 .

*Micarea ANTERIOR (Nyl.) Hedl. - on trunks of Picea obovata, 5; on trunks of Pinus sylvestris, 6.

*Micarea denigrata (Fr.) Hedl. - on fallen trees of Picea obovata, 2, 4; on trunks of Populus tremula, 6.

\#MicRocalicium Disseminatum (Ach.) Vain. - on trunks of Picea obovata, on standing deadwood of Picea obovata; 1-3, 5.

MiRiQuidicA LEUCOPHAEA (Flörke ex Rabenh.) Hertel \& Rambold - on boulders and rocks; 2.

*Montanelia Panniformis (Nyl.) Divakar et al. on soil; 7 .

*Montanelia sorediata (Ach.) Divakar et al. - on boulders and rocks; 1, 2 .

Mycobilimbia CARNEOAlBida (Müll. Arg.) S. Ekman $\&$ Printzen - on trunks of Picea obovata, 5; on trunks of Salix caprea; 6. Confirm. D. Himelbrant, 2015.

MycoBILIMBIA EPIXANTHOIDES (Nyl.) Vitik. et al. - on stumps; 1. Confirm. D. Himelbrant, 2015.

Mycoblastus AfFinis (Schaer.) T. Schauer - on trunks of Betula pubescens and Picea obovata; 2, 5; on trunks of Pinus sylvestris, 6.

Mycoblastus SANGUinarius (L.) Norman - on trunks of Betula pubescens and Picea obovata, on standing deadwood of Picea obovata, on rocks and boulders; 1-7.

*Mrcocalicium subtile (Pers.) Szatala - on trunks of Picea obovata, on standing deadwood of Picea obovata and Pinus sylvestris; 2.

+Naetrocymbe punctiformis (Pers.) R. C. Harris - on trunks of Sorbus aucuparia; 3-5. Confirm. D. Himelbrant, 2015.

Nephroma Arcticum (L.) Torss. - on soil; 3.

NePHROMA Bellum (Spreng.) Tuck. - on trunks of Salix caprea; 1 ; on trunks of Sorbus aucuparia; 3. 
Nephroma Resupinatum (L.) Ach. - on standing deadwood of Betula pubescens; 5 .

OCHROLECHIA ALBOflaVescens (Wulfen) Zahlbr. - on trunks of Picea obovata; 2, 4, 5. The specimens contain variolaric, lichesterinic and protolichesterinic acids.

OCHROLECHIA ANDROGYNa (Hoffm.) Arnold - on boulders and rocks, on trunks of Betula pubescens and Picea obovata; 1, 3, 5. The specimens contain gyrophoric, lecanoric acids and fatty acids called "androgyna B unknowns 1, 3" (Kukwa, 2011).

OCHROLECHIA FRIGIDA (Sw.) Lynge - on soil; 4.

*OCHROLECHIA MAHLUENSIS Räsänen - on trunks of Picea obovata, Betula pubescens and Sorbus aucuparia, on standing deadwood of Picea obovata and Betula pubescens; 2, 4-6. The specimens contain gyrophoric and lecanoric acids.

OCHROLECHIA MICROSTICTOIDEs Räsänen - on trunks of Picea obovata, on standing deadwood of Picea obovata, 2, 4; on trunks of Pinus sylvestris, 5 . The specimens contain variolaric and lichesterinic acids.

*Ophioparma Ventosa (L.) Norman - on boulders and rocks; $1,2$.

PARMELIA OMPHALODES (L.) Ach. subsp. OMPHALODES - on boulders and rocks; $2,5$.

Parmelia saxatilis (L.) Ach. - on boulders and rocks; $2,5$.

PaRmelia sulcata Taylor - on trunks of Picea obovata and Betula pubescens, on standing deadwood of Betula pubescens and Picea obovata; 1-7.

PARMEliopsis AmBigua (Wulfen) Nyl. - on trunks of Picea obovata and Sorbus aucuparia, on standing deadwood of Picea obovata; 1-7.

PARMELIOPSIS HYPEROPTA (Ach.) Vain. - on trunks of Picea obovata, on standing deadwood of Picea obovata; $1-7$.

Peltigera aphthosa (L.) Willd. - on soil; 3-5. Confirm. O. Vitikainen, 2013.

Peltigera Degenil Gyeln. - on base of Salix caprea; 1. Det. O. Vitikainen, 2013.

Peltigera malacea (Ach.) Funck - on soil; 2, 4. Confirm. O. Vitikainen, 2013.

Peltigera membranacea (Ach.) Nyl. - on base of Salix caprea; 2. Det. O. Vitikainen, 2013.

*Peltigera occidentalis (Å. E. Dahl) Kristinsson - on soil; 1-4. Det. O. Vitikainen, 2013.

Pertusaria Amara (Ach.) Nyl. - on trunks of Picea obovata and Betula pubescens, on standing deadwood of Picea obovata; 1-5.
*Pertusaria borealis Erichsen - on trunks of Picea obovata; 2,4 . The thalli contain fumarprotocetraric acid complex.

*Pertusaria Carneopallida (Nyl.) Anzi ex Nyl. - on trunks of Sorbus aucuparia; 1-5.

PERTUSARIA DACTYLINA (Ach.) Nyl. - on trunks of Picea obovata and Betula pubescens; 3, 4.

*Pertusaria Geminipara (Th. Fr.) C. Knight ex Brodo - on trunks of Betula pubescens and Picea obovata, on soil; 3-5.

PERTUSARIA OPHTHALMiza (Nyl.) Nyl. - on trunks of Sorbus aucuparia; 1.

*Pertusaria sommerfeltiI (Flörke ex Sommerf.) Flörke - on trunks of Picea obovata; 4.

Placynthiella icmalea (Ach.) Coppins \& P. James - on soil, on rotting wood; $1,2$.

*Placynthiella oligotropha (J. R. Laundon) Coppins \& P. James - on soil; 2. Det. G. Urbanavichus, 2014.

Placynthiella uliginosa (Schrad.) Coppins \& P. James - on soil; 2.

Platismatia glauca (L.) W. L. Culb. \& C. F. Culb. - on trunks of Picea obovata and Betula pubescens, on standing deadwood of Picea obovata, on boulders; 1-7.

Platismatia noRvegica (Lynge) W. L. Culb. \& C. F. Culb. - on trunks of Picea obovata; 2.

*Porpidia albocaerulescens (Wulfen) Hertel \& Knoph - on boulders and rocks; 5 .

Porpidia Cinereoatra (Ach.) Hertel \& Knoph - on boulders and rocks; 2.

Porpidia CRUSTUlata (Ach.) Hertel \& Knoph - on boulders and rocks; 1, 2, 4, 5 .

*Porpidia Flavicunda (Ach.) Gowan - on boulders and rocks; $2,4$.

Pseudevernia furfuracea (L.) Zopf - on trunks of Betula pubescens, 3; on trunks of Picea obovata; 1, 2, 5 .

PsiloleChia LuCIDA (Ach.) M. Choisy - on boulders; 1.

*Pycnora sorophora (Vain.) Hafellner - on trunks of Picea obovata, 4; on trunks of Pinus sylvestris, 6. The specimens contain alectorialic acid.

RAmalina THRAUSTA (Ach.) Nyl. - on trunks of Picea obovata; 5.

RHIZOCARPON BADIOATRUM (Flörke ex Spreng) Th. Fr. - on boulders and rocks; 1, 2, 4.

*Rhizocarpon Copelandil (Körb.) Th. Fr. - on boulders and rocks; $1,2$.

*Rhizocarpon eupetreum (Nyl.) Arnold - on boulders and rocks; $1,2$. 
RHIZOCARPON GEOGRAPHICUM (L.) DC. - on boulders and rocks; 1, 2, 4.

RHIZOCARPON HOCHSTETTERI (Körb.) Vain. - on boulders and rocks; 1, 2, 5 .

RHIZOCARPON REDUCTUM Th. Fr. - on boulders and rocks; 2.

*Rhizocarpon viridiatrum (Wulfen) Körb. - on boulders and rocks; 2.

*Rimularia limborina Nyl. - on boulders and rocks; 2.

Rinodina miLvina (Wahlenb.) Th. Fr. - on boulders and rocks; 2.

*Rinodina mniaraea (Ach.) Körb. var. mniaraea on trunks of Sorbus aucuparia and Populus tremula; 1. Confirm. D. Himelbrant, 2015.

*Rinodina tURfaCea (Wahlenb.) Körb. var. ECRUSTACEA (Vain.) H. Olivier - on trunks of Salix caprea; 6. Confirm. D. Himelbrant, 2015.

+ +SAREA Difformis (Fr.) Fr. - on resin of Picea obovata; 4.

$+{ }^{*}$ Sarea Resinae (Fr.) Kuntze - on resin of Picea obovata; 4.

*SColiciosporum Chlorococcum (Graewe ex Stenh.) Vězda - on trunks of Betula pubescens; 2,5 .

Stereocaulon grande (H. Magn.) H. Magn - on soil; 1. Det. T. Ahti, 2014.

Stereocaulon paschale (L.) Hoffm. - on soil, on primary soil over boulders; $2-5$. Confirm. T. Ahti, 2014.

*Stereocaulon saxatile H. Magn. - on soil, on primary soil over boulders; 3-5. Det. T. Ahti, 2014.

STEREOCAUlON SUbCORALlOIDES Nyl. - on soil; 2, 4. Det. T. Ahti, 2014.

THAMnOlia Vermicularis (Sw.) Schaer. - on soil; $4,6$.

*THELIDIUM PYRENOPHORUM (Ach.) Körb. - on boulders and rocks; 4.

TRAPEliopsis FleXUosa (Fr.) Coppins \& P. James on standing deadwood of Picea obovata; 1, 2.

TRAPELIOPSIS GRANUlOSA (Hoffm.) Lumbsch - on soil; 2, 3, 5 .

Tuckermanopsis CHLOROPHYLla (Willd.) Hale - on trunks of Picea obovata, Betula pubescens and Sorbus aucuparia; 1-7.

UMBilicARIA DEUSTA (L.) Baumg. - on boulders and rocks; 2.

UMBILICARIA HYPERBOREA (Ach.) Hoffm. - on boulders and rocks; 1.

UMBILICARIA TORREFACTA (Lightf.) Schrad. - on boulders and rocks; 2,5 .
Usnea dasopoga (Ach.) Nyl. - on trunks of Picea obovata, on standing deadwood of Picea obovata; 1-7.

Usnea GLABRescens (Nyl. ex Vain.) Vain. ex Räsänen - on trunks of Picea obovata, Betula pubescens, 4; on trunks of Picea obovata, 5, 6 .

UsNeA SUbFloridAna Stirt. - on trunks of Picea obovata and Salix caprea, 1-7.

VARICELlaRIA RHODOCARPA (Körb.) Th. Fr. - on trunks of Sorbus aucuparia, Picea obovata, Betula pubescens, on standing deadwood of Picea obovata; $1-7$.

Violella fuCATA (Stirt.) T. Sprib. - on trunks of Picea obovata; 2 . The specimens contain atranorin and fumarprotocetraric acid.

VUlPICIDA PINASTRI (Scop.) J.-E. Mattsson \& M. J. Lai - on trunks of Picea obovata, Betula pubescens and Sorbus aucuparia, on standing deadwood of Picea obovata; 1-7.

*XYLOGRAPHA DIFFORMIS Vain. - on standing deadwood of Picea obovata; 2-5.

*XYlogRaPHA PALlens (Nyl.) Malmgren - on standing deadwood of Picea obovata, on trunks of Picea obovata, on standing deadwood of Pinus sylvestris; $2-5$.

Xylographa PARAllela (Ach.: Fr.) Fr. - on standing deadwood of Picea obovata; 2, 4, 5.

XYlogRAPHA VITILIGO (Ach.) J. R. Laundon - on standing deadwood of Picea obovata; 2, 3, 6 . The specimens contain stictic acid complex.

XYLOPSORA FRIESII (Ach.) Bendiksby \& Timdal - on trunks of Picea obovata; 1, 2, 5.

\section{DISCUSSION}

223 lichen species and three subspecies belonging to 85 genera were found in the rocky forest communities of Olovgora. The most species-rich genera were Cladonia (42 species), Lecanora (8), Bryoria (7) and Rhizocarpon (7). Genera with a lower number of species (5-6) followed: Cetraria, Lecidea, Ochrolechia, Peltigera, Pertusaria; other genera were represented by four species or less.

A total of 82 taxa are new records for the mainland area of Arkhangelsk Region. Bryoria glabra has been reported for the first time in European Russia. Two species included in the Red Data Book of Arkhangelsk Region (2008) were recorded in Olovgora: Cladonia bellidiflora and Lobaria pulmonaria. Lobaria pulmonaria is protected in the Russian Federation (Red Data Book 
of Russian Federation, 2008). In the neighboring territory of Karelia, 11 species of the given list are regionally protected (Red Data Book of Karelian Republic, 2007): Bryoria bicolor, Bryoria nadvornikiana, Evernia divaricata, Hypogymnia bitteri, Lobaria pulmonaria, Lobaria scrobiculata, Nephroma bellum, Peltigera degenii, Ramalina thrausta, Thamnolia vermicularis, and Varicellaria rhodocarpa. Eight species are included in the Red Data Book of East Fennoscandia (Kotiranta et al., 1998): Bryoria bicolor, Bryoria nadvornikiana, Chaenotheca subroscida, Lobaria pulmonaria, Lobaria scrobiculata, Peltigera degenii, Ramalina thrausta, Stereocaulon grande, and Varicellaria rhodocarpa.

The substrate type analysis has shown that corticolous lichens dominated in the lichen species composition of Olovgora (Fig. 2). A total of 125 species ( $56 \%$ of the lichen flora) were found on the bark of trees, and 46 of them also occurred on wood. Among the studied phorophytes, the richest lichen diversity (89 species, $40 \%$ of the lichen flora) was observed on the trunks and branches of Picea obovata. On the bark of Betula pubescens 43 species (19\%) were found, on Sorbus aucuparia - 29 species (13\%), on Salix caprea -11 species (5\%). The group of lignicolous lichens contained 67 species $(30 \%$ of the lichen flora), of which typical lignicolous lichens are Calicium trabinellum, Cyphelium inquinans, Icmadophila ericetorum, Lecanora hypopta, Micarea denigrata, Trapeliopsis flexuosa, and Xylographa spp. The terricolous lichen communities included 59 species $(27 \%)$, of which 35 species were only found on the soil. Half of the group of ground lichens was represented by species of the genus Cladonia. Thamnolia vermicularis was rather common on the soil,

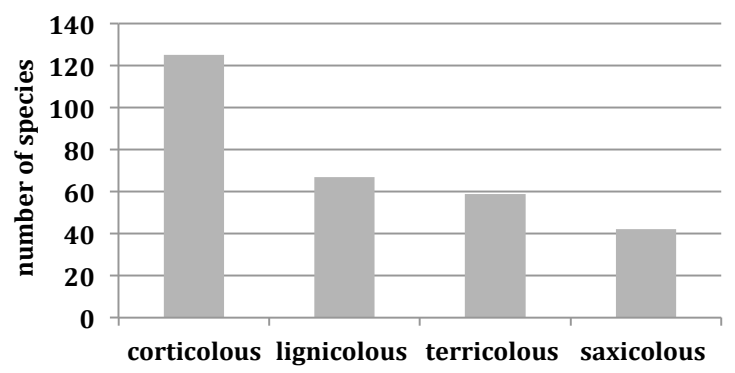

Fig. 2. Number of lichen species of different groups according to their substrate preferences in forest rocky communities of Olovgora. as well as species of the genera Peltigera and Stereocaulon. The saxicolous lichens were represented by 42 species (19\% of the lichen flora), characterized by a high substrate specificity (38 species were found on rocks only). Most of the species developed epilithic thalli: Aspicilia laevata, Cystocoleus ebeneus, Psilolechia lucida, Rhizocarpon spp. and Umbilicaria spp.

Thus, the lichen species composition of Olovgora is typical for old-growth forests of the boreal zone. The comparison of the species list with that of the lowland territory of Pinezhsky Nature Reserve (Zakharchenko, 1989; Zakharchenko \& Sokolova, 1989; Puchina et al., 2000) and Nature Park Kozhozero (Fadeeva, 2006) revealed that $50 \%$ of the species composition was the same. However, the altitudinal gradient and the proximity to the sea bring in arctic and oceanic species into the lichen biota.

Among the identified lichens of Olovgora, 214 occurred within the permanent sample plots, within the territory less than 0.5 ha. During the study of the mountain by a walking method on the area of about 25 ha, just nine species were added to the list of lichens. Obviously, the study of the lichen species composition by fixed sample plots makes it possible to obtain more complete information on the species diversity in the study area. The geobotanical transects along the slopes included a wide variety of conditions, heterogeneity of relief forms and substrates.

We suggest that the studied lichen species composition of mountain Olovgora reflects the high biodiversity potential of the lichen biota of the Vetreny Poyas ridge. This can be explained by the studied forest communities, the oldgrowth forests, as indicated by the presence of a large number of protected species and indicator species of old-growth forests. Furthermore, the species richness is also caused by a wide range of substrates: living trees of various species, decaying wood, crystalline rocks. In addition, the lowland landscape and geographic position cause the presence of arctic lichen species (Arthrorhaphis citrinella, Flavocetraria nivalis, Cladonia subfurcata, Nephroma arcticum, Thamnolia vermicularis etc.), and the proximity to the sea - the presence of sub-oceanic and oceanic species (Platismatia norvegica, Cladonia cornuta subsp. groenlandica). 
The rock forest communities of the Vetreny Poyas ridge might be considered as refuges, centers of biodiversity, probably not only for lichens. The nature of this area is of great interest for study and protection.

\section{ACKNOWLEDGEMENTS}

We would like to express our gratitude to our colleagues T. Ahti, D. E. Himelbrant, L. A. Konoreva, L. Myllys, J. Pykälä, G. P. Urbanavichus, and $\mathrm{O}$. Vitikainen for their consultations and assistance in species identification. The reported study was partially supported by the Ministry of Education and Science of the Russian Federation (project No. 6.724.2014/k); additional support was given by the Komarov Botanical Institute of the Russian Academy of Sciences (institutional research project No. 01201255601), the Russian Foundation for Basic Research (research grant 14-04-01411) and of Saint-Petersburg State University (research grant 1.37.151.2014). We are grateful to the reviewer for the valuable corrections and recommendations, which have improved the quality of our work.

\section{REFERENCES}

Andreev, M. P., Kotlov, Yu. V. \& Makarova, I. I. 1996. Checklist of lichens and lichenicolous fungi of the Russian Arctic. The Bryologist 99(2): 137-169. http:/ / dx.doi.org/ 10.2307/3244545

Chkhobadze, A. B. 1997. To studies of the lichen flora of old parks of Vologda region. Bulletin of Main Botanical Garden 175: 66-72. (In Russian).

Fadeeva, M. A. 2006. Lichens. In: The nature and historical cultural heritage of Kozhozero land. Arkhangelsk, pp. 75-102. (In Russian).

Fadeeva, M. A., Golubkova, N. S., Vitikainen, O. \& Ahti, T. 2007. Conspectus of lichens and lichenicolous fungi of the Republic of Karelia. Petrozavodsk. 194 pp. (In Russian).

Fadeeva, M. A. \& Kravchenko, A. V. 2005a. Lichen biota of large forest massive on the territories of indigenous taiga (on example of the Nature park "Kozhozersky", Arkhangelsk region. In: Proceedings of the 6th International Conference "Problems of Forest Phytopathology and Mycology", September 18-22, Moscow-Petrozavodsk. Moscow-Petrozavodsk, pp. 340-346. (In Russian).

Fadeeva, M. A. \& Kravchenko, A. V. 2005b. Lichensindicators of old-growth forests in the territory of Nature Park "Kozhozersky" (Arkhangelsk region). In: Proceedings of the Third Melehouskih readings dedicated to the 100th anniversary of J. S. Mele- hova (September 15-16). Arkhangelsk, pp. 28-32. (In Russian).

Glushkovskaya, N. B. 2013. Lichens of main forest biotopes on the watershed between the Northern Dvina and Pinega rivers in the Northwestern Russia. In: Landscape and biological diversity on the watershed between the northern Dvina and Pinega rivers. Saint-Petersburg, pp. 80-86. (In Russian).

Gromtsev, A. N. (ed.) 2008. Rupestrian landscapes of White Sea Karelian Coast: natural characteristics, economic utilization, conservation. Petrozavodsk. 212 pp. (In Russian).

Handbook of the lichens of Russia. 1996-2008. Vol. 6, 1996, 203 pp. Vol. 7, 1998, 166 pp. Vol. 8, 2003, 277 pp. Vol. 9, 2004, 339 pp. Vol. 10, 2008, 339 pp. St. Petersburg. (In Russian).

Handbook of the lichens of the USSR. 1971-1978. Vol. 1, 1971, 412 pp. Vol. 2, 1974, 283 pp. Vol. 3, 1975, 275 pp. Vol. 4, 1977, 344 pp. Vol. 5, 1978, 305 pp. Leningrad. (In Russian).

Kotiranta, H., Uotila, P., Sulkava, S. \& Peltonen, S.-L. (eds). 1998. Red Data Book of East Fennoscandia. 1998. Helsinki. $351 \mathrm{pp}$.

Kukwa, M. 2011. The lichen genus Ochrolechia in Europe. Fundacja Rozwoju Uniwersytetu Gdańskiego, Gdańsk. 309 pp.

Kulikova, V. V., Kulikov, V. S. \& Bychkova, Y. V. 2007. Revising the volcano-plutonic system "Volcano Loach - Ruyga intrusion". Geology and Mineral Resources of Karelia. Proceedings of KRC RAS, Petrozavodsk 10: 69-81. (In Russian).

McCune, B., Ahti, T. \& Duncan, C. M. 2006. Hypogymnia incurvoides (Parmeliaceae), a little-known Russian species discovered in eastern North America. The Bryologist 109(1): 80-84. http://dx.doi. org/ 10.1639/0007-2745(2006)109[0080:HIPAL $\mathrm{R}] 2.0 . \mathrm{CO} ; 2$

Nordin, A., Moberg, R., Tønsberg, T., Vitikainen, O., Dalsätt, Å., Myrdal, M., Snitting, D. \& Ekman, S. 2011. Santesson's Checklist of Fennoscandian Lichen-forming and Lichenicolous Fungi. Ver. April 29, 2011 - http://130.238.83.220/santesson/ home.php (25 December 2014).

Notov, A. A., Urbanavichus, G. P. \& Katauskayte, L. A. 2006. Materials to the lichen flora of Valdai and related physiographic provinces. In: Lichen flora of Russia: state and future prospects. Proceedings of the international conference dedicated to the 120 th anniversary of V. Savich. Saint-Petersburg, pp. 167-175. (In Russian).

Orange, A., James, P. W. \& White, F. J. 2001. Microchemical methods for the identification of lichens. British Lichen Society, London. 101 pp.

Pystina, T. N. \& Hermansson, J. 2013. Lichen diversity of Komi Republic: the most important results and prospects of further investigations. In: Proceedings of the XIII Congress of the Russian Botanical Society and the conference "Scientific basis for the protection and sustainable use of plant cover of 
the Volga basin", 16-22 September. Togliatti, pp. 205-207. (In Russian).

Puchina, L. V., Goryachkin, S. V., Rykov, A. M. et al. 2000. Structure and dynamics of natural components of Pinezhsky Nature Reserve (Northern Taiga ETP, Arkhangelsk region). Biodiversity and geodiversity in karst areas. Arkhangelsk. 267 pp. (In Russian).

Rassadina, K. A. 1929. Lichens of the Vologda region. Proceedings of reports of the Academy of Sciences of the USSR 9: 221-226. (In Russian).

Rassadina, K. A. 1967. New and interesting species and varieties of Hypogymnia. Novitates systematicae plantarum non vascularum 1967: 289-300. (In Russian).

Red Data Book of Arkhangelsk region. 2008. Arkhangelsk. 351 pp. (In Russian).

Red Data Book of Karelian Republic. 2007. Petrozavodsk. 368 pp. (In Russian).

Red Data Book of Russian Federation (plants and fungi). 2008. Moscow. 885 pp. (In Russian).

Sonina, A. V. \& Markovskaya, E. F. 2013. Species diversity of coastal epilithic lichens and ecological-physiological peculiarities of some species in the conditions of the Big Solovetsky Island (Arkhangelsk Region). Fundamental investigation 10: 1275-1279. (In Russian, English summary).

Tarasova, V. N. \& Sonina, A. V. 2011a. Ecologicalsubstrate analysis of lichens from rocky forest communities of national Park "Vodlozersky". In: Proceedings of Russian conference "Protected nature areas in the XXI century: the current state and prospects of development" dedicated to the 20th anniversary of the National Park "Vodlozersky”, June 1-3, Petrozavodsk. Petrozavodsk, pp. 245-249. (In Russian).
Tarasova, V. N. \& Sonina, A. V. 2011b. Lichens of rocky forest communities in the National Park "Vodlozersky" (Arkhangelsk region). In: Proceedings of Russian conference "Russian geobotany: history and perspectives”. St. Petersburg, pp. 237-240. (In Russian).

Tarasova, V. N. \& Sonina, A. V. 2012. Formation of soil cover depending on occurrence depth of crystalline rocks in rocky forest communities of National Park "Vodlozersky" (Arkhangelsk region). Proceedings of the Samara Scientific Center of the Russian Academy of Sciences 1 (5): 1379-1382. (In Russian, English summary).

Tarasova, V. N. 2014. Platismatia norvegica - a new lichen record from European Russia. Folia Cryptogamica Estonica 51: 131-134. http://dx.doi. org/ 10.12697 / fce.2014.51.15

Urbanavichus, G. P., Ahti T. \& Urbanavichene, I. N. 2008. Checklist of lichens and allied fungi of Murmansk region, Russia. Norrlinia 17: 1-80.

Zakharchenko, J. V. 1989. Lichens of Pinezhsky Nature Reserve. In: Algae, lichens, fungi and bryophytes in the reserves of Russian Federation. Proceedings of scientific papers of CSRL "Glavohota" of Russian Federation. Moscow, pp. 60-68. (In Russian).

Zakharchenko, J. V. \& Sokolova, S. V. 1989. Addition to the check list of lichens of Pinezhsky Nature Reserve. In: Algae, lichens, fungi and bryophytes in the reserves of Russian Federation. Proceedings of scientific papers of CSRL "Glavohota" of Russian Federation. Moscow, pp. 68-70. (In Russian). 